\title{
Bell Device
}

National Cancer Institute

\section{Source}

National Cancer Institute. Bell Device. NCI Thesaurus. Code C49843.

A device designed to make a ringing sound when struck. 